\title{
A study on effects of cash flow patterns and auditors' opinions in predicting financial distress
}

\author{
Fatemeh Namvar $^{\mathrm{a}^{*}}$, Khosro Faghani Makrani ${ }^{\mathrm{a}}$ and Asghar Karami ${ }^{\mathrm{b}}$
}

${ }^{a}$ Department of Management and Accounting, Semnan Branch, Islamic Azad University, Semnan, Iran ${ }^{b}$ Department of Management and Accounting, Allameh Tabataba'i University, Tehran, Iran

\section{CHR ON I C L E}

\section{Article history:}

Received May 12, 2013

Received in revised format

25 June 2013

Accepted 27 June 2013

Available online

June 292013

Keywords:

Financial distress

Cash flow patterns

Auditors'opinions

Going concern

\begin{abstract}
A B S T R A C T
Bankruptcy has been one of the most important issues among investors in stock market and there are literally different techniques for predicting bankruptcy. In this paper, we study on effects of cash flow patterns and auditors' opinions in predicting financial distress on some 80 selected firms traded on Tehran Stock Exchange over the period 2005-2011. In this study, the combination of cash flow patterns represent firm's resource allocations and operational capabilities interacted with their strategy choices. In additions, predictions about each individual cash flow components, operational, investment, financial, are derived from economic theory, which forms a basis for the life proxy. We use cash flow patterns in the decline stage and compare the results with auditors' opinions. The results indicate that cash flow patterns could predict financial distress companies in Iran. In addition, the effective cash flow patterns in predicting financial distress is more than auditors' feedbacks.
\end{abstract}

(C) 2013 Growing Science Ltd. All rights reserved.

\section{Introduction}

Bankruptcy is one of the most important events, which may be announced on any stock exchange and many investors prefer to have some insight about this news in advance. Altman (1968) and Beaver (1968) are believed to be the one who introduced a systematic approach to determine the likelihood of firms' bankruptcy. Fulmer et al. (1984) later introduced a model to determine the likelihood of bankruptcy for smaller firms. Hoshi et al. (1990) explored the idea that financial distress was expensive because free-rider problems and information asymmetries could create some troubles for firms to renegotiate with their creditors. They explained that firms in industrial groups invest more and sell more after the onset of distress than nongroup firms do. Opler and Titman (1994) reported that highly leveraged firms had lost substantial market share to their more conservatively financed competitors in industry downturns. A decline took place in the market value of equity and the results

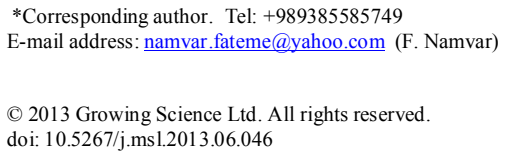


seemed to be consistent with the view that the indirect expenses of financial distress were significant and positive. Consistent with the theory that firms with specialized products were especially vulnerable to financial distress (Gordon, 1971), they reported that highly leveraged firms that engaged in research and development suffered the most in economically distressed periods. They also reported that the adverse consequences of leverage were more pronounced in concentrated industries.

Hertzel et al. (2008) examined the wealth impacts of distress and bankruptcy filing for suppliers and customers of filing firms. On average, essential wealth effects happen before and at bankruptcy filings and extend beyond industry competitors along the supply chain. Specifically, distress associated with bankruptcy filings was related to negative and substantial stock price impacts for suppliers. Supplier wealth impacts were more negative when intra-industry contagion was more severe. They also investigated the importance of industry structure, specialized product nature, and leverage on supply chain impacts.

Sun and Li (2008) puts forward a financial distress prediction technique based on weighted majority voting combination of multiple classifiers. The framework of multiple classifier combination system, model of weighted majority voting combination, basic classifiers' voting weight model and basic classifiers' selection principles were discussed in detail. Empirical experiment with Chinese listed companies' real world data indicated that the proposed could largely improve the average prediction accuracy and stability, and it was more suitable for financial distress prediction than single classifiers.

According to Sun and Li (2009) financial distress early warning is important for business bankruptcy prevention, and different quantitative prediction techniques based on financial ratios have been introduced. However, little attention has been devoted to the important role of experts' experiential knowledge and non-financial information. Sun and Li (2009) presented a group decision-making technique based on experts' knowledge and all types of financial or non-financial information to diagnose business financial distress. They designed a qualitative attribute set and its scoring criteria based on the risk factors of enterprise financial distress. They also offered a technique integrating linguistic label and interval value for decision makers to express their preference on attributes, and they designed a multi-expert negotiation mechanism for weighting attributes. Diagnosis on business financial distress was constructed through the grey evaluation method, which also attempted to detect the potential risks, which may cause financial distress. Case study of a real world company was also carried out to validate the proposed financial distress early warning technique based on group decision making.

Xiao et al. (2012) extended the research of multiple predictions to integrate with rough set and Dempster-Shafer evidence theory. They implemented rough set to determine the weight of each single prediction technique and utilized Dempster-Shafer evidence theory method as the combination method. They also discussed the research process for the financial distress prediction based on the proposed method and provided an empirical experiment with Chinese listed companies' real data to demonstrate the accuracy of their method.

\section{The proposed method}

In this study, we investigate the effects of cash flow patterns and auditors' opinions in predicting financial distress on some 80 selected firms traded on Tehran Stock Exchange over the period 20052011. To choose the suitable firms, we have considered some criteria as follows,

1. The firms must be listed on stock exchange prior to year 2004 .

2. No financial firm such as banks or insurance companies is allowed.

3. There must be no change on fiscal year. 
4. All necessary information for calculating necessary ratios as well as Tobin-q must be available.

The study groups 80 firms into two groups of bankrupted and non-bankrupted companies and using logistic regression technique processes a mathematical model. In our proposed model, we need to calculated the following independent variables,

$\mathrm{X}_{1}$ : Ratio of operating activities to total assets.

$\mathrm{X}_{2}$ : Ratio of return of investment to total assets.

$\mathrm{X}_{3}$ : Ratio of total pad tax to total assets.

$\mathrm{X}_{4}$ : Ratio of investment activities to total assets.

$\mathrm{X}_{5}$ : Ratio of financing activities to total assets.

We also consider a dummy variable, where one is associated with bankrupted firms and zero for other ones. In our study, we have used 80 observations each year and no information is reduced in any year. The output of logistic regression is also categorized into two groups of beginning and enters one. Table 1 shows details of the logistic regression analysis for the first group.

\section{Table 1}

The summary of the regression analysis for the first block

\begin{tabular}{llllll}
\hline Description & Intercept & Standard error & Sig. & df & Likelihood \\
\hline Year of bankruptcy & 0.00 & 0.224 & 0.000 & 1 & 1.000 \\
One year before bankruptcy & 0.00 & 0.224 & 0.000 & 1 & 1.000 \\
Two years before bankruptcy & 0.00 & 0.224 & 0.000 & 1 & 1.000 \\
\hline
\end{tabular}

Next, we present details of our findings on regression analysis for the second block. We first present details of Omnibus test. Table 2 demonstrates the summary of this test.

Table 2

The summary of Omnibus test

\begin{tabular}{llccc}
\hline Description & & Chi-Square & df & P-Value \\
\hline \multirow{3}{*}{ Year of bankruptcy } & Step & 62.109 & 5 & 0.000 \\
& Block & 62.109 & 5 & 0.000 \\
& Model & 62.109 & 5 & 0.000 \\
\hline \multirow{3}{*}{ One year before bankruptcy } & Step & 44.638 & 5 & 0.000 \\
& Block & 44.638 & 5 & 0.000 \\
& Model & 44.638 & 5 & 0.000 \\
\hline \multirow{3}{*}{ Two years before bankruptcy } & Step & 59.711 & 5 & 0.000 \\
& Block & 59.711 & 5 & 0.000 \\
& Model & 59.711 & 5 & 0.000 \\
\hline
\end{tabular}

As we can observe from the results of Table 2, Chi-Square values are statistically significant and we can enter variable $\mathrm{X}_{1}$ to $\mathrm{X}_{5}$ to our model. We also perform Log likelihood, Cox, Snell and Nagelkerke tests to find appropriate method for regression technique and Table 3 summarizes our findings,

\section{Table 3}

The summary of statistical observations

\begin{tabular}{lccc}
\hline Description & Log likelihood & Cox and Snell & Nagelkeke \\
\hline Year of bankruptcy & 48.794 & 0.540 & 0.720 \\
One year before bankruptcy & 66.266 & 0.428 & 0.570 \\
Two years before bankruptcy & 51.192 & 0.526 & 0.701 \\
\hline
\end{tabular}


The desirable value for all statistics is a number close to one. Therefore, the first model based on the year of bankruptcy seems to be more suitable than the second one and the second one would seem to perform better than the third one.

\section{The results}

In this section, we first present details of our findings for the implementation of logistic regression applied to data in the first block and Table 4 summarizes the results of our survey.

Table 4

The summary of statistics on logistic regression

\begin{tabular}{|c|c|c|c|c|c|c|c|c|c|c|c|c|}
\hline & \multicolumn{3}{|c|}{ Year of bankruptcy } & \multicolumn{3}{|c|}{$\begin{array}{c}\text { One year before } \\
\text { bankruptcy }\end{array}$} & \multicolumn{3}{|c|}{$\begin{array}{c}\text { Two years before } \\
\text { bankruptcy }\end{array}$} & \multicolumn{3}{|c|}{ Average forecasted } \\
\hline & \multicolumn{3}{|c|}{ Dependent variable } & \multicolumn{3}{|c|}{ Dependent variable } & \multicolumn{3}{|c|}{ Dependent variable } & \multicolumn{3}{|c|}{ Dependent variable } \\
\hline & 0 & 1 & success & 0 & 1 & success & 0 & 1 & success & 0 & 1 & success \\
\hline Non-bankrupted & 34 & 6 & 85 & 32 & 8 & 80 & 35 & 5 & 87.5 & 101 & 19 & 84.1 \\
\hline Bankrupted & 6 & 34 & 85 & 4 & 36 & 90 & 6 & 34 & 85 & 16 & 104 & 86.6 \\
\hline Success & & & 85 & & & 85 & & & 86.3 & & & 85.4 \\
\hline
\end{tabular}

As we can observe from the results of Table 4, the rate of prediction of financial stress for the firs and the second model is $85 \%$ while this rate for the third model is $86.3 \%$. On average, all models had over $85 \%$ rate of success for prediction of financial distress. Table 5 summarizes details of our results on logistic regression for the first block.

Table 5

The summary of logistic regression for the first block

\begin{tabular}{|c|c|c|c|c|c|c|}
\hline Year & Variable & Coefficient & Standard & Wald statistic & Sig. & $\mathrm{df}$ \\
\hline \multirow{6}{*}{ 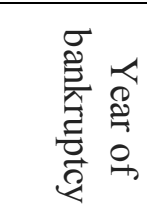 } & $\mathrm{X}_{1}$ & -12.146 & 6.669 & 3.317 & 0.069 & 1 \\
\hline & $X_{2}$ & 7.325 & 6.791 & 1.146 & 0.281 & 1 \\
\hline & $\mathrm{X}_{3}$ & 89.254 & 36.460 & 5.993 & 0.014 & 1 \\
\hline & $X_{4}$ & 26.251 & 13.801 & 3.618 & 0.057 & 1 \\
\hline & $\mathrm{X}_{5}$ & -9.923 & 6.596 & 2.263 & 0.132 & 1 \\
\hline & Intercept & 4.126 & 1.034 & 15.933 & 0.00 & 1 \\
\hline \multirow{6}{*}{ 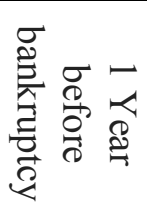 } & $\mathrm{X}_{1}$ & -0.546 & 2.058 & 0.070 & 0.791 & 1 \\
\hline & $X_{2}$ & 15.159 & 7.972 & 3.616 & 0.057 & 1 \\
\hline & $\mathrm{X}_{3}$ & 69.074 & 27.645 & 6.243 & 0.012 & 1 \\
\hline & $X_{4}$ & 15.242 & 6.974 & 4.776 & 0.029 & 1 \\
\hline & $\mathrm{X}_{5}$ & 2.808 & 4.226 & 0.441 & 0.506 & 1 \\
\hline & Intercept & 2.722 & 0.676 & 16.206 & 0.00 & 1 \\
\hline \multirow{6}{*}{ 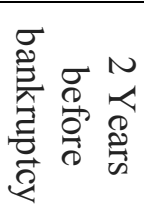 } & $\mathrm{X}_{1}$ & -19.859 & 8.615 & 5.313 & 0.021 & 1 \\
\hline & $\mathrm{X}_{2}$ & -6.246 & 10.705 & 0.340 & 0.560 & 1 \\
\hline & $\mathrm{X}_{3}$ & 129.835 & 40.269 & 10.395 & 0.001 & 1 \\
\hline & $\mathrm{X}_{4}$ & -4.509 & 9.767 & 0.213 & 0.644 & 1 \\
\hline & $\mathrm{X}_{5}$ & -6.517 & 8.124 & 0.644 & 0.422 & 1 \\
\hline & Intercept & 3.631 & 0.958 & 14.365 & 0.00 & 1 \\
\hline
\end{tabular}

As we can observe from the results of Table 5, most coefficients are statistically significant and we can confirm that cash flow numbers help prediction of financial distress. The second hypothesis of this survey investigates whether the results of cash analysis could provide better decisions compared with auditors' opinions. Therefore, we consider the following hypothesis

$\mathrm{H}_{0}$ : Financial cash flow ratios do not have more information than auditors' opinions.

$\mathrm{H}_{1}$ : Financial cash flow ratios maintain more information than auditors' opinions.

In order to investigate this hypothesis we consider two sides opinions, the model and auditors and the results are summarized in Table 6 as follows, 
Table 6

The summary financial distress observation on two groups

\begin{tabular}{lcccccccc}
\hline & \multicolumn{2}{c}{ Year of bankruptcy } & \multicolumn{2}{c}{ 1-year before bankruptcy } & \multicolumn{2}{c}{ 2-year before bankruptcy } & Total \\
& Distress & Safe & Distress & Safe & Distress & Safe & \\
\hline Cash flow method & 34 & 6 & 32 & 8 & 37 & 3 & 103 \\
& .85 & .15 & 0.80 & 0.2 & 0.925 & 0.075 & 0.856 \\
\hline Auditor's opinions & 19 & 21 & 18 & 22 & 21 & 19 & 58 \\
& 0.475 & 0.525 & 0.45 & 0.55 & 0.525 & 0.4755 & 0.4834 \\
\hline
\end{tabular}

Based on the information of Table 6 we may extract the mean and standard deviation from two groups of information and they are summarized in Table 7 as follows,

Table 7

The summary of mean and standard deviation of distressed firms

\begin{tabular}{lcccc}
\hline Model & Mean & Number & Standard deviation & Mean error \\
\hline Cash flow & 0.856 & 120 & 0.270 & 0.023 \\
Auditors' opinions & 0.483 & 120 & 0.493 & 0.044 \\
\hline
\end{tabular}

In addition, Table 8 demonstrates t-student test between two groups.

Table 8

The summary of t-student test

\begin{tabular}{lcccccc}
\hline \multicolumn{7}{c}{ Mean difference between two methods } \\
& Mean & Std. dev. & Mean error & t & df & Sig. \\
\hline Auditor and cash flow & 0.373 & 0.575 & 0.051 & 9.02 & 119 & 0.001 \\
\hline
\end{tabular}

The results of Table 8 indicate that there is, indeed, a difference between two groups when the level of significance is five percent and we can reject the null hypothesis in favor of alternative hypothesis. In other word, the likelihood of prediction of financial distress by auditors and cash flow method are 0.483 and 0.856 , respectively. This means the proposed cash flow method has a better chance for predicting bankruptcy. Therefore, the second hypothesis of this paper has been confirmed.

\section{Conclusion}

In this paper, we have presented an empirical investigation to find out whether or not we could get a better estimation on financial distress based on the cash flow information. The proposed study selected some firms from Tehran Stock Exchange and using logistic regression function compared the likelihood of bankruptcy obtained by the proposed method and auditor's analysis, statistically. The results of our study have indicated that the proposed study of this paper has better chance for predicting the financial distress.

\section{References}

Altman, E. I. (1968). Financial ratios, discriminant analysis and the prediction of corporate bankruptcy. The journal of finance, 23(4), 589-609.

Beaver, W. H. (1968). Alternative accounting measures as predictors of failure. The Accounting Review, 43(1), 113-122.

Fulmer, J. G., Moon, J. E., Gavin, T. A., \& Erwin, M. (1984). A bankruptcy classification model for small firms. Journal of Commercial Bank Lending,66(11), 25-37.

Gordon, M. J. (1971). Towards a theory of financial distress. The Journal of Finance, 26(2), 347-356. 
Hertzel, M. G., Li, Z., Officer, M. S., \& Rodgers, K. J. (2008). Inter-firm linkages and the wealth effects of financial distress along the supply chain. Journal of Financial Economics, 87(2), 374387.

Hoshi, T., Kashyap, A., \& Scharfstein, D. (1990). The role of banks in reducing the costs of financial distress in Japan. Journal of financial economics, 27(1), 67-88.

Opler, T. C., \& Titman, S. (1994). Financial distress and corporate performance. The Journal of Finance, 49(3), 1015-1040.

Sun, J., \& Li, H. (2008). Listed companies' financial distress prediction based on weighted majority voting combination of multiple classifiers. Expert Systems with Applications, 35(3), 818-827.

Sun, J., \& Li, H. (2009). Financial distress early warning based on group decision making. Computers \& Operations Research, 36(3), 885-906.

Xiao, Z., Yang, X., Pang, Y., \& Dang, X. (2012). The prediction for listed companies' financial distress by using multiple prediction methods with rough set and Dempster-Shafer evidence theory. Knowledge-Based Systems, 26, 196-206. 